\title{
Diagnostic investigations and prevalence of enteric fever in Ahmadu Bello University Teaching Hospital Shika-Zaria, Kaduna State, Nigeria
}

\author{
Igiri $\mathrm{BE}^{1,3 *}$, Inyang-Etoh $\mathrm{PC}^{1}$, Ejezie $\mathrm{GC}^{1}$, Jimoh $\mathrm{O}^{2}$, Sobo $\mathrm{MA}^{3}$ and Idoko $\mathrm{GO}^{3}$ \\ ${ }^{1}$ Department of Medical Laboratory Science, University of Calabar, Nigeria \\ ${ }^{2}$ Department of Medical Microbiology, ABUTH, Nigeria \\ ${ }^{3}$ Directorate of Research and Development, Nigerian Institute of Leather and Science Technology, Nigeria
}

\begin{abstract}
Enteric fever is a systemic infectious illness that poses public health challenge in developed and developing countries like Nigeria. This research work is aimed at determining the prevalence of typhoid fever infection among patients attending ABUTH Zaria-Kaduna State, Nigeria. Patients' biodata was obtained through structured questionnaire and diagnosis was done using venous blood sample collected from the study subjects. 216 blood samples were collected into blood culture bottles and Ethylene Diamine Tetra-acetic Acid (ETDA) bottles from the respondents and was analysed using cultural and Widal test techniques. 72 (33.3\%) had typhoid fever using Widal test and none (0.0\%) was positive for typhoid fever using blood culture. Bacterial isolates of medical significance, Staphylococcus aureus was detected in $10(4.6 \%)$ patients. The prevalence of typhoid fever was highest among the Huasa-Fulani ethnic group (35\%), those in the age group $>60$ years $(66.7 \%)$, those in tertiary education (42\%), the employed (64\%), those in the weight group 41-50 (49\%) and those who are married (44\%). The much talk on the prevalence of enteric fever in Zaria and other parts of Nigeria is due to the cheap and quick Widal test which is not reliable unlike the blood culture techniques. Diagnostic investigations of enteric fever required blood culture as confirmatory test and not the use of Widal test alone in other to avoid the intake of antibiotic by patients that do not need it.
\end{abstract}

\section{Introduction}

Enteric fever is an acute life threatening febrile illness caused by Salmonella Typhi and Paratyphi A, B, and C with high burden and deadly consequence [1]. Typhoid is an infectious disease characterized by clinical manifestations such as fever, abdominal pain, headache, enlargement of the spleen, malaise, transient rash, and with complications like intestinal perforation, hemorrhage, and perinephric abscess [2,3]. The disease causes devastating burden in many underdeveloped and developing countries, with recent estimates of global prevalence ranging between 11.9 to 26.9 million cases every year [4,5], and mortality estimates ranging between 129,000 and 161,000 yearly [4].

Enteric fever infection is acquired by fecal-oral routes and humans are the only true reservoir of Salmonella Typhi as chronic and carriers always serve as the ultimate source of infection [6-8]. The incubation period of $S$. Typhi is between 3 to 60 days, but symptoms are typically presented within 1 to 2 weeks of infection [9]. Typhoid fever is associated with high rate of morbidity and mortality especially in developing countries like Southeast Asia and Africa [10,11]. 5,700 cases of typhoid fever occur each year in the US, and $75 \%$ are acquired through international travel to these regions [12]. In the year 1900s, Mary Mallon was the first "healthy carrier" of typhoid fever in the United States [13], with an estimate of 47 infected people and three deaths.

Typhoid fever diagnosis requires laboratory confirmation because other common febrile diseases may present with similar signs and symptoms. Classical Widal agglutination test and blood culture may be used for the confirmation of enteric fever, but these methods have several limitations [14-17]. Among the limitations that could affect result of this technique are lack of reliable diagnostic test, volume of blood culture, time of collection, intake of antibiotics before laboratory test and insufficient culture media [10,18-20]. Bone marrow aspirate culture is the gold standard for the diagnosis of typhoid fever [21-23]. The use of duodenal aspirate culture has shown satisfactory result [24] but has not found widespread acceptance because of poor tolerance of duodenal aspiration especially in children [25].

Higher Widal agglutination could occur as a result of latent and post-infectious diseases like pneumonia, tuberculosis, amoebiasis, rickettsial, rheumatoid arthritis and chronic active hepatitis. Widal test has high sensitivity for diagnosis of typhoid fever without good specificity and should be replaced with more accurate diagnosis [26]. Therefore, this study was undertaken to evaluate the prevalence and the extent to which blood culture techniques is accurate against the quick diagnosing Widal test among febrile patients attending Ahmadu Bello University Teaching Hospital Zaria, Kaduna State-Nigeria.

Correspondence to: Igiri Bernard Egwu, Department of Medical Laboratory Science, University of Calabar, Calabar, Nigeria, Tel: +234-7068597797, E-mail: egwubernard2@gmail.com

Key words: enteric fever, diagnosis, salmonella typhi, blood culture, prevalence

Received: January 08, 2018; Accepted: February 15, 2018; Published: February 28, 2018 


\section{Materials and methods}

\section{Study area}

The study was carried out in Ahmadu Bello University Teaching Hospital, Zaria of Kaduna State, North West Nigeria. The coordinates are along lat. $10^{\circ} .20^{\prime} \mathrm{N}$ and long. $7^{\circ} .45^{\prime} \mathrm{E}$. Kaduna State is located at the centre of Northern Nigeria. The study was approved by the Health Research Ethics Committee of Ahmedu Bello University Teaching Hospital (ABUTH) Shika-Zaria, Kaduna State, and assigned number ABUTHZ/HREC/U10/2016 and the date of clearance was $20^{\text {th }}$ June 2016. The study was carried out from July to November 2016.

\section{Study design}

The study was a cross-sectional hospital-based study used to determine the prevalence of typhoid fever in Ahmadu Bello University Teaching Hospital, Zaria, Kaduna State.

\section{Target population}

All patients attending General Out Patients Department of ABUTH with febrile illness were recruited for the study.

\section{Inclusion criteria}

Patients of both sexes and all age groups with febrile illness attending Ahmadu Bello University Teaching Hospital, Shika, Zaria, were enrolled in the study.

\section{Exclusion criteria}

Patients with catheterization done within 3 days before the study were excluded

\section{Data collection}

Structured questionnaire were given to patients/guardians who gave their consent in order to get information concerning their sociodemographic details and symptoms of the disease.

\section{Sampling techniques}

A purposive sampling technique was used.

\section{Sample collection and handling}

Blood sample was collected at General Out Patients Department (GOPD) of ABUTH Shika, Kaduna State, Nigeria. Each participant's upper arm was fastened with a tourniquet; the site for blood collection was wiped with cotton wool soaked in methylated spirit to clean and sterilized the area. $5 \mathrm{ml}$ syringe with a $21 \mathrm{~g}$ needle was used to withdraw $4 \mathrm{mls}$ of blood from each patient.

Dry cotton wool was placed at the point of venepuncture while the needle was gently removed and sharps were safely disposed in the sharp box. $2 \mathrm{ml}$ of the blood was aseptically introduced into a culture bottle containing Brain Heart Infusion broth, the remaining $2 \mathrm{mls}$ of the blood into an Ethylene Diamine Tetra-acetic Acid (EDTA) and then centrifuged to obtained serum for Widal test.

\section{Diagnosis of typhoid fever}

\section{Blood culture}

$2 \mathrm{ml}$ of the blood samples that were directly inoculated into a culture bottle containing Brain Heart Infusion broth was incubated at $37^{\circ} \mathrm{C}$ for 7 days. This was sub-cultured on day 3 and 7 on MacConkey agar and Blood agar base [27,28]. Inoculated blood culture media was discarded as negative after 10 days if there is no growth.

\section{Widal test}

Widal agglutination tests was done on all blood samples by rapid slide titration technique using commercially prepared antigen suspension (Omega diagnostic kit) for somatic $(\mathrm{O})$ and flagella $(\mathrm{H})$ antigens [29]. On a white rectangular tile, a drop of each reactant in the following order, paratyphi $\mathrm{A}, \mathrm{B}, \mathrm{C}$ and typhi $\mathrm{D}$ of $\mathrm{O}$ antigen and paratyphi $\mathrm{A}, \mathrm{B}, \mathrm{C}$ and typhi $\mathrm{D}$ of $\mathrm{H}$ antigen were placed in the first and second row. Using Pasteur's pipette, a drop of serum from each blood sample was added to each reactant and mixed with a stirrer, and the stirrer was dried with cotton wool after each stir. The tile was gently rocked with hands for one minute and each spot was observed for agglutination. Significant titres were considered positive for any serum sample with antibody titre greater than or equal to 1 in 160 for somatic $(\mathrm{O})$ and flagella $(\mathrm{H})$ antibodies.

\section{Statistical analysis}

Data were analyzed using statistical package for social science (SPSS), version 23. The data obtained was subjected to Chi-square test to determine the significant association between the patterns of distributions.

\section{Results}

The prevalence rate of enteric fever using Widal test at significant antibody titre $\geq 1$ in 160 for Salmonella typhi and Salmonella paratyphi A, B, C was $33.3 \%$ and none $(0.0 \%)$ using blood culture (Table 1 ). Among participants with respect to age, education and marital status (Table 2), those in the age group greater than 60 years had the highest prevalent rate of typhoid fever 4 (66.7\%) while 51-60 years age group had the least incidence rate of $1(11.1 \%)$. More females $48(34.0 \%)$ than the males 24 (32.0\%) were positive for typhoid fever among the age groups.

On the educational status, the tertiary had the highest incidence of typhoid fever 30(42.0\%), of which the female had 19(39.0\%) and males $11(50.0 \%)$ while the primary had the least $11(25.0 \%)$. In the marital status, the married had $48(44.0 \%)$ prevalence of typhoid fever while the single had 24(23.0\%) (Table 2)

However, in the weight group, the highest prevalence of typhoid fever 17 (49.0\%) was recorded among 41-50 group while the age group 11-20 had no typhoid fever. Also, the Hausa-fulani had the highest prevalence of typhoid fever 48 (35.0\%) than other tribes. The gainfully employed had $48(64.0 \%)$ prevalence of typhoid fever while the unemployed had 24(17.0\%) among the occupational groups (Table 3).

On the clinical presentation among patients with febrile illness in the study area (Figure 1), $60 \%$ of the study subjects had headache, followed by $59.7 \%$ having fever while diarrhoea had the least rate of $2.3 \%$.

\section{Discussion}

Infection caused by $S$. Typhi remains an important public health problem, particularly in developing countries. Morbidity and mortality attributable to typhoid fever are once again increasing with the emergence and worldwide spread of $S$. Typhi strains that are resistant to most previously useful antibiotics.

In the study area and Nigeria at large, there have been reports of sporadic outbreaks of enteric fever which has not been always confirm resulting to scantiness in quality data on the incidence of typhoid in many parts of Nigeria reporting outbreaks [30]. The isolation of 
Table 1. Overall prevalence of enteric fever infection using widal and blood culture techniques.

\begin{tabular}{|c|c|c|c|}
\hline Illness & No. Examined & No. Positive (Widal) \% & No. Positive (Blood Culture) \% \\
\hline Enteric Fever & 216 & $72(33.3)$ & $0.0(0.0)$
\end{tabular}

Table 2. Prevalence of typhoid fever among participants in relation to age, education and marital status.

\begin{tabular}{|c|c|c|c|c|c|c|}
\hline Age group (years) & No. Examined & No. Positive (\%) & Male Examined & Male Positive (\%) & Female Examined & Female Positive (\%) \\
\hline $1-10$ & 38 & $6(16)$ & 11 & $3(27.3)$ & 27 & $3(11.1)$ \\
\hline $11-20$ & 52 & $14(30)$ & 26 & $6(23)$ & 26 & $8(30.8)$ \\
\hline $21-30$ & 55 & $24(44)$ & 15 & $5(33.3)$ & 40 & $19(48)$ \\
\hline $31-40$ & 38 & $16(42)$ & 10 & $7(70)$ & 28 & $9(32.1)$ \\
\hline $41-50$ & 18 & $7(38.9)$ & 6 & $1(16.7)$ & 12 & $6(50)$ \\
\hline $51-60$ & 9 & $1(11.1)$ & 3 & $0(0.0)$ & 6 & $1(16.7)$ \\
\hline$>60$ & 6 & $4(66.7)$ & 4 & $2(50)$ & 2 & $2(100)$ \\
\hline Total & 216 & $72(33)$ & 75 & $24(32)$ & 141 & $48(34)$ \\
\hline Education & $\mathrm{X}^{2}=6.05$ & $\mathrm{df}=3$ & $p>0.05$ & & & \\
\hline Non-formal & 36 & $13(36)$ & 10 & $1(10)$ & 26 & $12(46)$ \\
\hline Primary & 44 & $11(25)$ & 16 & $6(38)$ & 28 & $5(17.9)$ \\
\hline Secondary & 65 & $18(28)$ & 27 & $6(22.2)$ & 38 & $12(32)$ \\
\hline Tertiary & 71 & $30(42)$ & 22 & $11(50)$ & 49 & 19(39) \\
\hline Total & 216 & $72(33)$ & 75 & $24(32)$ & 141 & $48(34)$ \\
\hline Marital Status & $\mathrm{X}^{2}=1.13$ & $\mathrm{df}=1$ & $p>0.05$ & & & \\
\hline Married & 110 & $48(44)$ & 29 & $14(48.3)$ & 81 & $34(42)$ \\
\hline Single & 106 & $24(23)$ & 46 & $10(21.7)$ & 60 & $14(23)$ \\
\hline Total & 216 & $72(33)$ & 75 & $24(32)$ & 141 & $48(34)$ \\
\hline
\end{tabular}

Table 3. Distribution of typhoid fever among participants with respect to weights, ethnicity and occupation.

\begin{tabular}{|c|c|c|c|c|c|c|}
\hline Weights & $\begin{array}{c}\text { No. } \\
\text { Examined }\end{array}$ & $\begin{array}{l}\text { No. Positive } \\
(\%)\end{array}$ & Male Examined & $\begin{array}{c}\text { Male Positive } \\
\text { (\%) }\end{array}$ & Female Examined & $\begin{array}{c}\text { Female Positive } \\
\text { (\%) }\end{array}$ \\
\hline $11-20$ & 10 & $0(0.0)$ & 3 & $0(0.0)$ & 7 & $0(0.0)$ \\
\hline $21-30$ & 36 & $7(19.4)$ & 14 & $4(28.6)$ & 22 & $3(13.6)$ \\
\hline $31-40$ & 25 & $9(36)$ & 12 & $4(33.3)$ & 13 & $5(38.4)$ \\
\hline $41-50$ & 35 & $17(49)$ & 9 & $3(33.3)$ & 26 & $14(54)$ \\
\hline $51-60$ & 42 & $17(40)$ & 19 & $7(36.8)$ & 23 & $10(42)$ \\
\hline $60-70$ & 28 & $10(36)$ & 10 & $4(40)$ & 18 & $6(33.3)$ \\
\hline $70-80$ & 22 & $8(36.4)$ & 3 & 1(33.3) & 19 & $7(36.8)$ \\
\hline $81-90$ & 14 & $3(21.4)$ & 4 & $1(25)$ & 10 & $2(20)$ \\
\hline $91-100$ & 4 & $1(25)$ & 1 & $0(0.0)$ & 3 & $1(33.3)$ \\
\hline Ethnicity & $\mathrm{X}^{2}=1.79$ & $\mathrm{df}=3$ & $p>0.05$ & & & \\
\hline HausaFulani & 136 & $48(35)$ & 53 & $16(30)$ & 83 & $32(39)$ \\
\hline Yoruba & 24 & $7(29.2)$ & 6 & $2(33.3)$ & 18 & $5(27.8)$ \\
\hline Igbo & 7 & $2(28.6)$ & 1 & $0(0.0)$ & 6 & $2(33.3)$ \\
\hline Others & 49 & $15(31)$ & 15 & $6(40)$ & 34 & $9(26.5)$ \\
\hline Total & 216 & $72(33)$ & 75 & $24(32)$ & 141 & $48(34)$ \\
\hline Occupation & $X^{2}=4.5$ & $\mathrm{df}=1$ & $p>0.05$ & & & \\
\hline Employed & 75 & $48(64)$ & 31 & $12(38.7)$ & 44 & $36(82)$ \\
\hline Unemployed & 141 & $24(17)$ & 44 & $12(27.3)$ & 97 & $12(12)$ \\
\hline Total & 216 & $72(33)$ & 75 & $24(32)$ & 141 & $48(34)$ \\
\hline
\end{tabular}

$\mathrm{X}^{2}=8.81, \mathrm{df}=8, p>0.05$ for Weight group

$S$. Typhi from blood culture techniques of patients' blood has been regarded as definitive diagnosis of typhoid fever [22] but many clinical laboratories in developing countries lack adequate infrastructure to perform blood culture and so depend on the cheaper serological tests for diagnosis of typhoid fever.

The prevalence of enteric fever 33.3\% using Widal test was higher than the results of the findings of Alhassan et al. [31] who reported $26 \%$ of the 300 patients in Sokoto Nigeria, Shukla et al. [32] who reported $28 \%$ of the 200 respondents in Barabanki District of U.P. India, but however in contrast with the work of Nwuzo et al. [33] who reported $21.2 \%$ of the 250 participants in Abakaliki, Ebonyi State, Samatha et al. [34] who reported $22.6 \%$ of the 589 patients in Guntur, Mbuh et al. [35] who reported $10.1 \%$ of the 218 patients in Zaria, Kaduna State. The result of Widal agglutination test in this study recorded high prevalence of Salmonella typhi and could be attributed to haemolytic anemia and malaria parasites specific factors which increases the patients vulnerability to Non-typhoidal Salmonella serotypes (NTS) as reported by Mbuh et al. [35].

Higher proportions of Salmonella paratyphi and less Salmonella typhi were encountered. This suggests that greater proportion of the population were exposed to Salmonella paratyphi than Salmonella typhi. However, this result is in contrast with the findings of Mohammed et al. [36]; Olubuyide, [7] and Osime and Eghafona, [37], who reported that Nigeria is endemic for typhoid and that paratyphoid are less commonly encountered. 


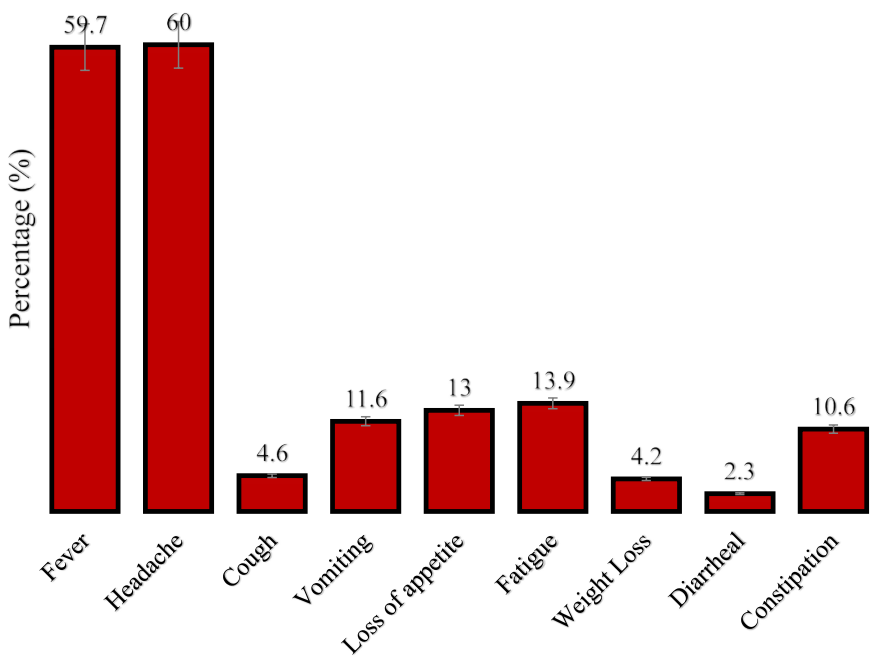

Figure 1. Clinical presentation among patients with febrile illness in the study area.

The high prevalence of typhoid fever could be as a result of cross reaction between typhoid fever and malaria during Widal test and this may lead to high level of agglutination which might in turn lead to unnecessary exposure of the patient to antibiotics [38].

\section{Conclusion}

Patients with typhoid fever cases should be carefully examined and samples collected for bacteriology and serology be appropriately diagnose to avoid false diagnosis of typhoid fever. Diagnostic investigations of enteric fever required blood culture as confirmatory test and not to use the Widal test alone in other to avoid the intake of antibiotic by patients that do not need it.

\section{Acknowledgement}

The authors are grateful to the management and staff of ABUTH which facilities were used for the study. We are highly indebted to the staff of Medical Microbiology Department of ABUTH, Shika-Zaria especially Dr A. Ibrahim, Mr Mbah, Mr Iliya Kigbu and Mallam Musa.

\section{Consent}

Written informed consent was sought from patients/guardian prior to recruitment into the study. A detail of the study was explained to them in English and Hausa language for those who could not understand English Language. Participation in the study was voluntary and those who refused to take part in the study were still given due attention without any bias.

\section{Ethical approval}

Ethical clearance for this study was obtained from Health Research Ethics Committee of Ahmedu Bello University Teaching Hospital (ABUTH) Shika-Zaria, Kaduna State, Nigeria

\section{Competing interests}

Authors have declared that no competing interests exist.

\section{References}

1. Wain J, Hendriksen RS, Mikoleti ML, Keddy KH, Ochiai RL (2015) Typhoid fever. Lancet 385: 1136-1145. [Crossref]

2. Pegues DA, Miller SI (2015) Salmonellosis. In: Kasper DA, Hauser SL, Jameson JL, Fauci AS, Longo DL, Losalzo J (Edtr). Harrison's Principles of Internal Medicine. (19th edn), New York: McGraw Hill Education: 1049-1055.
3. Devi S, Bhat KS, Kanungo R, Rajan RP (2015) Salmonella enterica var. typhi as an uncommon cause of perinephric abscess: A case report and review of literature. J Curr Res Sci Med 1: 41-43.

4. Mogasale V, Maskery B, Ochiai RL, Lee JS, Mogasale VV, et al. (2014) Burden of typhoid fever in low-income and middle-income countries: a systematic, literaturebased update with risk factor adjustment. Lancet Glob Health 2: 570-580. [Crossref]

5. Buckle GC, Fisher Walker CL, Black RE (2012) Typhoid fever and Paratyphoid fever: systematic review to estimate global morbidity and mortality for 2010. J Glob Health 2: 010401. [Crossref]

6. Dougan G, Baker S (2014) Salmonella enterica serovar Typhi and the pathogenesis of typhoid fever. Annu Rev Microbiol 68: 317-336. [Crossref]

7. Olubuyide TO (1992) Factors that may contribute to death from typhoid infection among Nigerians. West Afr J Med 11: 112-115. [Crossref]

8. Butter T (1992) Typhoid fever: In: Wyngaarden JB, Smith LH, Bennett J (Edtr). Ceci textbook of Medicine. (9th edn), Philadelphia, USA: WB Saunders CO: 1690-1692.

9. Chatterjee A M Varman, CO'Keefe (2014) Pediatric Salmonella Infection Clinical Presentation.” Medscape. Accessed Jan 5, 2016.

10. Parry CM, Hien TT, Dougan G, White NJ, Farrar JJ (2002) Typhoid fever. $N$ Engl J Med 347: 1770-1782. [Crossref]

11. Hirose K, Tamura K, Sagara H, Watanabe H (2001) Antibiotic suscetibilities of Salmonella enteric serovarTyphi and Salmonella enteric serovar paratyphi A isolated from patients in Japan. Antimicrobial Agents Chemotherapy 45: 956-958. [Crossref]

12. Centers for Disease Control and Prevention (CDC) (2013) Typhoid Fever. Accessed January 5, 2016. [http://www.cdc. gov/nczved/divisions/dfbmd/ diseases/ typhoid _fever/]

13. Rosenberg J (2015) Typhoid Mary: The Sad Story of Women Responsible for Several Typhoid Outbreaks. Accessed January 5, 2016. [http://history1900s.about.com/ od/1900s/a/typhoidmary.htm]

14. House D, Wain J, Ho VA, Diep TS, Chinh NT, et al. (2001) Serology of typhoid fever in an area of endemicity and its relevance to diagnosis. J Clin Microbiol 39: 1002-1007. [Crossref]

15. Levine MM, Grados O, Gilman RH, Woodward WE, Solis-Plaza R, et al. (1978) Diagnostic value of the Widal test in areas endemic for typhoid fever. Am J Trop Med Hyg 27: 795-800. [Crossref]

16. Parry CM, Hoa NT, Diep TS, Wain J, Chinh NT, (1999) Value of a single-tube Widal test in diagnosis of typhoid fever in Vietnam. J Clin Microbiol 37: 2882-2286. [Crossref]

17. House D, Chinh NT, Diep TS, Parry CM, Wain J, et al. (2005) Use of paired serum samples for serodiagnosis of typhoid fever. J Clin Microbiol 43: 4889-4890. [Crossref]

18. Baker S, Favorov M, Dougan G (2010) Searching for the elusive typhoid diagnostic. BMC Infect Dis 10: 45. [Crossref]

19. Guerra-Caceres JG, Gotuzzo-Herencia E, Crosby-Dagnino E, Miro-Quesada M, Carillo-Parodi C (1979) Diagnostic value of bone marrow culture in typhoid fever. Trans R Soc Trop Med Hyg 73: 680-683. [Crossref]

20. Wain J, Diep TS, Ho VA, Walsh AM, Hoa TTN, et al. (1998) Quantitation of bacteria in blood of typhoid fever patients and relationship between counts and clinical features, transmissibility, and antibiotic resistance. J Clin Microbiol 36: 1683-1687. [Crossref]

21. Gasem MH, Dolmans WM, Isbandrio BB, Wahyono H, Keuter M, et al. (1995) Culture of Salmonella typhi and Salmonella paratyphi from blood and bone marrow in suspected typhoid fever. Trop Geogr Med 47: 164-167. [Crossref]

22. Hoffman SL, Edelman DC, Punjabi NH, Lesmana M, Cholid A, et al. (1986) Bone marrow aspirate culture superior to streptokinase clot culture and $8 \mathrm{ml} 1: 10$ bloodto-broth ratio blood culture for diagnosis of typhoid fever. Am J Trop Med Hyg 35: 836-839. [Crossref]

23. Soewandojo E, Suharto U, Hadi U, Frans P, Prihartini E (1998) Comparative results between bone marrow culture and blood culture in the diagnosis of typhoid fever. Medical Journal of Indonesia 7: 209.

24. Benavente L, Gotuzzo J, Guerra O, Grados H, Bravo N (1984) Diagnosis of typhoid fever using a string capsule device. Trans R Soc Trop Med Hyg 78: 404-406. [Crossref]

25. Vallenas C, Hernandez H, Kay B, Black R, Gotuzzo E (1985) Efficacy of bone marrow, blood, stool and duodenal contents cultures for bacteriologic confirmation of typhoid fever in children. Pediatr Infect Dis 4: 496-498. [Crossref] 
26. Khelowd AM, Bashar SN (2017) Evaluate the efficiency of Widal test in diagnosis of typhoid Fever in arriving patients to Kirkuk hospitals. Tikrit Journal of Pure Science 22.

27. Duguid JP, Marmion BP, Swain RH (1984) Medical Microbiology; a Guide to the Laboratory Diagnosis and Control of infection 1:315-316.

28. Cheesbrough M (2002) District Laboratory Practice in Tropical Countries. (Part 2). Cambridge University Press: 182-186.

29. Cheesebrough M (2005) District Laboratory Practice in Tropical Countries. (Part $1,2^{\text {nd }}$ edn), New York, Cambridge University Press: 454.

30. Abayomi W (2009) Typhoid Fever, Staphylococcus and Other Stroies. [http://www. nigeriavillagesquare.com/articles/typhoid-fever-staphylococcus-and-other-stories.html]

31. Alhassan HM, Shidali NN, Manga SB, Abdullahi K, Hamid KM (2012) Co-infection profile of Salmonella typhi and malaria parasites in Sokoto-Nigeria. Global Journal of Science Engineering and Technology 2: 13-20.

32. Shukla S, Pant H, Sengupta C, Chaturvedi P, Chaudhary BL (2014) Malaria and typhoid, do they co-exist as alternative diagnosis in tropics? A tertiary care hospital experience. International Journal of Current Microbiology and Applied Science 3: 207-214.
33. Nwuzo AC, Onyeagba RA, Iroha IR, Oji AE (2009) Parasitological, bacteriological and cultural determination of prevalence of malaria parasite (Plasmodium falciparum) and typhoid fever co-infection in Abakaliki, Ebonyi State. Scientific Research and Essay 4: 966-971.

34. Samatha P, Chalapathi RK, Sai Sowmya B (2015) Malaria Typhoid Co-infection among Febrile Patients. Journal of Evolution of Medical and Dental Sciences 4: 11322-11327.

35. Mbuh FA, Gialadima M, Ogbadu L (2003) Rate of co-infection with malaria parasites and Salmonella typhi in Zaria, Kaduna State. Annals of African Medicine 2: 64-67.

36. Mohammed I, Chikwem JO, Gashau W (1992) Determination of Widal agglutination of the baseline titre for the diagnosis of typhoid fever in two Nigerian states. Scand $J$ Immunol Suppl 36: 153-156. [Crossref]

37. Osime CO, Eghafona N (2003) Typhoid Antibodies in a Healthy Population. Diagnostic significance in Nigeria. The Nigeria Journal of Science Resources 4: 54-60.

38. Meseret B, Belay T, Getachew F, Mengistu E, Bamlaku E (2014) Malaria, typhoid fever and their co-infection among febrile patients at a rural health center in North west Ethiopia: A cross sectional study. Adv Med: 1-8.

Copyright: @2018 Egwu BI. This is an open-access article distributed under the terms of the Creative Commons Attribution License, which permits unrestricted use, distribution, and reproduction in any medium, provided the original author and source are credited. 